Informatio: Journal of Library and Information Science Vol. 1(2), 121-146, Juli 2021

ISSN 2775-0043 (Online)

\title{
Strategi promosi perpustakaan: Film animasi sebagai media edukasi bagi pemustaka
}

\author{
Atiqa Nur Latifa Hanum a* \\ aFakultas Keguruan dan Ilmu Pendidikan Universitas Tanjungpura Pontianak
}

\begin{abstract}
Abstrak
Film Upin dan Ipin episode Aku Sebuah Buku mengusung tema berbeda dari film animasi pada umumnya yakni representasi perpustakaan pada budaya setempat yang dikemas dengan lukisan gambar hidup yang artistik. Popularitas perpustakaan hingga masa kini belum juga meningkat, oleh sebab itu perlu strategi promosi sebagai upaya mengedukasi pemustaka untuk meningkatkan popularitas. Penelitian ini bertujuan menangkap pesan dari simbol-simbol yang ditayangkan, dampaknya, serta efektivitas media dalam mempengaruhi penonton. Penelitian ini akan dibahas secara naratif dengan pendekatan kualitatif untuk melihat tanda dan penanda yang ditampilkan dalam tayangan tersebut. Informan yang digunakan terdiri dari 11 orang anak yang telah menonton film ini. Analisis datanya dilakukan dalam tiga tahap, yakni reduksi data, penyajian data, dan penarikan simpulan. Uji validitas, peneliti melakukan triangulasi sumber dan member check. Hasil menunjukkan bahwa realitas, representasi, dan ideologis yang dimaknai oleh informan dan para pakar yang menunjukkan film ini sedang membangun citra positif sebuah perpustakaan dengan budaya masyarakat yang terbuka terhadap informasi, memiliki minat yang besar terhadap buku, bahkan manfaat yang diperoleh setelah membaca buku bisa langsung diaplikasikan. Setelah menonton, para informan mendapatkan pengetahuan mengenai aktivitas di perpustakaan secara keseluruhan dan termotivasi untuk melakukan hal yang sama seperti yang mereka lihat di film. Itu artinya film Upin dan Ipin berhasil mengedukasi informan tentang peran dan fungsi perpustakaan dalam kehidupan sehari-hari. Hasil penelitian ini juga mempertegas bahwa film dapat dijadikan sebagai salah satu media edukasi bagi pemustaka di mana mampu menginformasikan dan mempersuasi kalangan anak-anak untuk mengunjungi perpustakaan sebagai salah satu strategi promosi perpustakaan yang efektif.
\end{abstract}

Kata kunci: Promosi perpustakaan; Film animasi; Media edukasi

Korespondensi: Atiqa Nur Latifa Hanum, Fakultas Keguruan dan Ilmu Pendidikan, Universitas Tanjungpura, Jl. Profesor Dokter H. Hadari Nawawi, Bansir Laut, Kec. Pontianak Tenggara, Kota Pontianak, Kalimantan Barat 78115, Indonesia

Email: atiqa.nur@fkip.untan.ac.id

http://jurnal.unpad.ac.id/informatio

DOI: https://doi.org/10.24198/inf.v1i2.31077

Received: November 2020; Accepted: Juli 2021; Published: Juli 2021

(C) Informatio 2021. This is an open access article under the CC BY-SA license 


\title{
Library promotion strategy: Animated films as educational media for users
}

\begin{abstract}
The animated series of Upin and Ipin has a unique series entitled "Aku Sebuah Buku". It show a library representation of the local culture which is packaged with artistic living painting to attract and ease the understanding the meaning of the symbols displayed. The popularity of libraries has not increased until now, threfore a promotional strategy is needed as an effort to educate users to increase popularity. This study used a narrative method with a qualitative approach to find out the signs and markers displayed in the series. The respondents were 11 childrens who watched this film. The data analysis was carried out in three stages, namely data reduction, data presentation, and ideology interpreted by respondents and experts show that this film is building a positive image of a library for the open-minded society who has the biggest interest in books. It can be concluded that animation film has succesfull and become reliable as an educational medium alternative ineffective library promotion strategy in informing and persuading shildren to visit the library which can be seen from their interest and motivation to visit the library and oing the same things after watching the animated film of Upin and Ipin.
\end{abstract}

Keywords: Library promotion; Animated film; Educational media

\section{PENDAHULUAN}

Promosi merupakan suatu usaha yang dilakukan oleh seseorang/lembaga untuk mengajak kepada orang lain agar menggunakan produk, jasa, dan ide yang ditawarkan. Secara umum promosi dilakukan dengan tujuan untuk mempengaruhi sikap, pengetahuan dan perilaku target promosi untuk membujuk mereka membeli atau menggunakan barang atau jasa yang ditawarkan (Adhyria, 2015).

Banyak cara yang dilakukan oleh sebuah perusahaan agar produk dan jasa yang mereka miliki laris di pasaran yaitu salah satunya dengan cara promosi. Demikian pula dengan perpustakaan, mengingat rendahnya apresiasi dan minat masyarakat terhadap perpustakaan maka promosi perpustakaan sangat perlu dilakukan. Meskipun perpustakaan bergerak di bidang jasa layanan yang berbasis nirlaba tetapi perpustakaan juga harus melakukan promosi agar produk dan jasa yang mereka tawarkan mampu menarik minat dan bisa dimanfaatkan oleh konsumen mereka yakni para pengguna perpustakaan. Promosi dilakukan bukan hanya untuk menginformasikan, tetapi juga sebagai alat yang digunakan untuk mempersuasif para konsumen sehingga timbul kesetiaan dari mereka agar senantiasa menggunakan tanpa ragu atau dalam arti kata lain menciptakan loyalitas. Promosi sangat erat hubungannya dengan pemasaran. Promosi merupakan bagian dari bauran pemasaran yang akan membuat suatu lembaga atau organisasi akan semakin berkembang (Hackley, 2005).

Perlu ditekankan, loyalitas adalah tujuan akhir yang dituju. Oleh sebab itu, perpustakaan harus bekerja keras melakukan kegiatan pemasaran. American Marketing Association (AMA) menjelaskan tentang definisi pemasaran sebagai suatu fungsi organsasi dan serangkaian proses untuk menciptakan, mengkomunikasikan, dan memberikan nilai 
kepada pelanggan dan untuk mengelola hubungan pelanggan dengan cara yang menguntungkan organisasi dan pemangku kepentingan (Kotler \& Keller, 2009). Kepuasan pelanggan merupakan elemen terpenting dalam pengambilan keputusan membeli atau menggunakan, atau bahkan sebaliknya (Yao, 2012)). Berbicara tentang pemasaran, ada sepuluh tipe entitas yang dipasarkan, yakni barang, jasa, acara, pengalaman, orang, tempat, properti (hak kepemilikan), organisasi, informasi, dan ide. Kesepuluh entitas tersebut akan diterima baik oleh konsumen dengan saluran yang tepat sebagai strategi komunikasi yang dilakukan suatu lembaga dalam aktivitas promosinya.

Berdasarkan entensitas pemasaran tersebut dalam melakukan promosinya perpustakaan harus mampu mengenalkan barang/jasa yang ditawarkan seperti; bahan pustaka apa saja yang dimiliki oleh perpustakaan, jenis layanan apa saja yang bisa dimanfaatkan oleh pengguna, dan fasilitas lain apa saja yang disediakan oleh perpustakaan untuk memenuhi kebutuhan pengguna dengan aman dan nyaman. Perlu diketahui bahwa tujuan promosi perpustakaan adalah memperkenalkan semua manfaat perpustakaan dan pengguna dapat mengetahui fungsi perpustakaan. Dengan adanya promosi, diharapkan masyarakat mengetahui pelayanan yang diberikan oleh perpustakaan sehingga membuat mereka tertarik untuk mengunjungi dan memanfaatkan koleksi serta layanan perpustakaan (Adhyria, 2015).

Pada hakekatnya promosi perpustakaan merupakan proses memperkenalkan seluruh kegiatan, layanan, dan koleksi yang ada di perpustakaan kepada masyarakat. Promosi perpustakaan dilakukan dengan tujuan agar masyarakat sebagai pengguna perpustakaan dapat memanfaatkan seluruh jasa dan produk yang ada di perpustakaan dengan baik (Afriani \& Yunaldi, 2012). Oleh sebab itu promosi memiliki peran penting dalam mencapai visi dan misi perpustakaan, salah satu faktor keberhasilan sebuah perpustakaan adalah perpustakaan yang banyak dikunjungi oleh pemustaka, koleksinya dimanfaatkan dengan baik, fasilitas yang memadai dan selain itu juga ditunjang dengan sumber daya manusia yang berkompeten.

Semiotika merupakan ilmu yang mempelajari tentang tanda-tanda dan maknanya. Semiotika juga berpengaruh pada kegiatan promosi. Orang-orang yang melihat kegiatan promosi akan membaca tanda yang diberikan sebagai "serangkaian tanda-tanda" (UmikerSebeok, 2012). Hackley menambahkan bahwa tanda-tanda tersebut meliputi copy, typeface, soundtrack, positioning, image, colour, and objects yang maknanya tersembunyi, yang menjadi pusat dan memaksa target pasar untuk meyakini promosi yang mereka lihat (Hackley, 2005). Mengartikan tanda yang diberikan targantung pada konteks, penerima, dan kode komunikasi yang dikirimkan dalam bentuk ekspektasi budaya pengirim dan penerima tanda tersebut. Tanda-tanda tersebut dikemas dalam perencanaan media promosi. Media sangat dibutuhkan untuk memperkenalkan suatu barang atau jasa yang akan dipromosikan oleh suatu perpustakaan. Tujuannya untuk menyampaikan informasi 
penting mengenai barang atau jasa perpustakaan sebagai pesan yang akan diinterpretasikan oleh para pemustaka sebagai konsumennya. Oleh sebab itu, dalam strategi pemilihan media promosi harus memastikan koherensi antara media, merek, dan pelaksana kreatif.

Ide dasar semiotika adalah pesan dan kode. Satu-satunya cara pesan dapat dikirim dari satu orang ke orang lain adalah dengan cara menggunakan kode. Encoding adalah proses mengubah pikiran atau komunikasi ke dalam pesan yang disampaikan. Decoding merupakan kebalikannya yaitu proses membaca pesan dan memahami maksud pesan. Terdapat beraneka ragam jenis kode yang banyak digunakan dalam komunikasi (Mudjiyanto \& Nur, 2013).

Berdasarkan perspektif semiotika, setiap orang harus memiliki pemahaman yang sama, tidak hanya pada kata yang diucapkan dan tata bahasa yang digunakan dalam lingkungan masyarakat atau latar belakang budaya, hal ini bertujuan agar komunikasi dapat berlangsung dengan efektif. Komunikator dan komunikan harus mempunyai sistem hubungan yang mengacu pada pemahaman tanda yang sama terhadap pesan yang disampaikan. Jika tidak, maka akan terjadi salah pemahaman dalam komunikasi. Sehingga pesan yang disampaikan tidak dapat diterima dengan baik.

Semiotika memiliki kemampuan yang baik dalam menganalisa dan mendeskripsikan sebuah data dalam bentuk tulisan, audio, visual, musik dan lainnya. Oleh sebab itu, semiotika juga mempunyai peran penting dalam komunikasi. Promosi sebagai salah bentuk strategi komunikasi juga dilakukan dalam berbagai bentuk media, apalagi zaman sekarang banyak sekali media yang bisa dimanfaatkan sebagai ajang promosi barang/jasa yang dimiliki baik dalam bentuk cetak maupun digital seperti; brosur, katalog, banner, papan reklame, film, iklan tv, media sosial, dan lainnya.

Salah satu media promosi yang efektif mempengaruhi pasar sasaran yaitu film. Film merupakan media artistik yang sanggup memainkan ruang dan waktu, mengembangkan maupun mempersempit batasan-batasan, merepresentasikan dunia nyata bahkan khayal untuk membuat para penonton terbawa ke dalam alur cerita yang ditampilkan (Wahjuwibowo, 2013). Sebagai media baru, film memberikan beberapa kelebihan dibandingkan beberapa media promosi lainnya karena pesan-pesan yang ingin disampaikan oleh produser ditunjukkan secara audio dan visual yang akan menimbulkan emosional sehingga penonton dapat terbawa perasaan dan pengalaman berdasarkan simbol-simbol dan pesan yang disampaikan. Selain itu, film juga memiliki segmentasi pasar yang jelas berdasarkan genre-nya, sehingga berpotensi memberi dampak yang luas dan respon yang sesuai dengan harapan si produser. Film juga mampu menyampaikan pesan dengan baik melalui pilihan karakter yang menarik dan bervariasi, tema cerita yang seru, latar belakang dan pengemasan yang lebih realistis seperti kehidupan sehari-hari. Meskipun dikemas dalam bentuk animasi film masih tetap menjadi pilihan favorit banyak 
orang, jadi tak sedikit juga lembaga atau instansi yang memanfaatkan film sebagai salah satu bentuk media promosi untuk menarik minat target pasarnya.

Film serial animasi Upin dan Ipin yang ditayangkan di MNCtv menjadi salah satu film animasi favorit anak-anak. Episode demi episodenya membawakan tema yang berbeda-beda. Durasi film kurang lebih 16 menit 5 detik tanpa iklan atau lebih kurang 30 menit dengan tambahan iklan. Pada hari Rabu, 26 Desember 2018 tayang episode "Aku Sebuah Buku" (Amiruddin, 2018). Dalam episode ini menceritakan tentang berbagai lapisan masyarakat yang berkunjung ke perpustakaan dan memanfaatkan koleksi buku dan layanan lainnya yang ada di Perpustakaan Ilmu.

Tema film yang unik dan jarang sekali ada film animasi yang menampilkan representasi perpustakaan ini sangat menarik untuk memancing minat masyarakat terhadap perpustakaan. Anak-anak sebagai target utama dan orang tua sebagai target potensial dapat merepresentasikan perpustakaan melalui film ini. Berbeda dengan film animasi lainnya yang lebih banyak menyuguhkan fantasi yang bersifat khayal, episode ini menarik untuk dikaji karena memberikan warna dan nuansa yang dapat bermanfaat bagi anak-anak yang menontonnya terhadap pengetahuan akan keberadaan perpustakaan. Fokus permasalahan dalam penelitian ini yaitu bagaimana promosi yang dilakukan melalui media film dapat merepresentasikan perpustakaan bagi anak-anak yang menontonnya. Tujuannya untuk mengetahui strategi promosi perpustakaan melalui media yang efektif kepada calon pemustaka potensial agar eksistensi perpustakaan tetap terjaga. Saat ini memang sangat diperlukan strategi promosi yang kreatif dan inovatif dengan memanfaatkan berbagai media yang ada, perpustakaan sebagai sumber informasi tentunya harus mampu bersaing agar fungsinya dimanfaatkan dengan maksimal.

\section{METODE PENELITIAN}

Penelitian ini dilakukan secara kualitatif menggunakan metode naratif. Penelitian kualitatif ialah penelitian riset yang bersifat deskriptif dan cenderung menggunakan analisis serta lebih menonjolkan proses dan makna (Noor \& Wahyuningratna, 2017). Film animasi Upin dan Ipin menjadi obyek penelitian karena tema cerita yang diusung menarik dan unik, berfokus merepresentasikan perpustakaan. Segmentasi penonton film juga terukur, anak-anak mulai usia 2 -12 tahun. Tentunya penayangan film ini akan memberikan dampak bagi para penontonnya berupa pengetahuan bahkan pengalaman yang dapat mereka sebarluaskan kepada orang lain berdasarkan daya tangkap mereka terhadap film tersebut. 
Penelitian ini dilakukan selama kurun waktu 6 bulan. Tujuannya untuk mengetahui realitas, representasi, dan ideologi pesan-pesan yang terkandung dalam film animasi Upin dan Ipin episode Aku Sebuah Buku secara verbal maupun nonverbal yang meliputi aspek tanda-tanda secara keseluruhan, seperti objek, simbol, ikon, orang, warna, teks yang merepresentasikan perpustakaan dalam setiap adegan yang membentuk alur cerita film (Umiker-Sebeok, 2012). Secara umum, penonton biasanya hanya akan memaknai sebuah film secara menyeluruh. Namun sebenarnya ada banyak makna yang tersirat di dalam alur sebuah film baik berupa makna denotasi, konotasi, bahkan mitos.

Perlu diketahui bahwa realitas yang dimaksud berupa kenyataan yang terjadi di tengah masyarakat berkaitan dengan tema yang diangkat dalam film ini. Representasi di sini juga berupa pemaknaan oleh sekelompok masyarakat dalam sebuah kebudayaan yang ditampilkan dalam setiap scene film ini. Sedangkan ideologi yang dimaksud adalah pandangan yang diyakini kebenarannya oleh masyarakat. Makna denotasi diartikan sebagai makna sesuai apa adanya atau primer dari suatu kata. Tidak menyimpan unsur makna lain atau tersembunyi yang terkandung dalam kata tersebut. Sedangkan makna konotasi lebih menunjukkan pada makna yang tersembunyi atau tidak sebenarnya pada kata tersebut.

Dengan pemaparan naratif, peneliti berusaha memaknai tanda-tanda dan kodekode yang ditayangkan. Teknik analisis data dilakukan dalam tiga tahap: reduksi data, penyajian data, dan penarikan simpulan. Uji validitas, dilakukan dengan triangulasi sumber dan member check. Untuk melihat keberhasil media film sebagai alat promosi, digunakan sebelas orang anak yang telah menonton film ini sebagai informan serta dua orang pakar untuk validitas triangulasi sumber.

Kesebelas informan tersebut dipilih berdasarkan umur dan kesamaan pendidikan untuk mewakili secara general anak-anak usia sekolah dasar dan menengah pertama yang dipilih secara acak. Namun meskipun demikian, informan dianggap layak karena memenuhi kriteria yang diprasyaratkan yakni telah menonton film animasi Upin dan Ipin episode Aku Sebuah Buku. Selain itu juga dianggap representatif. Sedangkan pemilihan pakar didasarkan oleh kepakarannya dalam bidang kesusastraan sehingga mengetahui dengan jelas tanda-tanda baik denotasi dan konotasi yang disampaikan oleh tokoh-tokoh dalam film melalui objek, simbol, ikon, warna, maupun teks yang direpresentasikan.

Secara garis besar ada dua aspek yang akan peneliti ungkap, aspek tanda meliputi simbol dan ikon. Sedangkan aspek kode meliputi pesan nonverbal yang ditunjukkan melalui ekspresi pemeran film dan tata ungkap visual melalui fokus pengambilan gambar. Pengambilan gambar dalam analisis ini mengikuti terminologi tipe shot mulai dari extreme wide shot yang menunjukkan lingkungan di mana subyek film berada, 
wide shot untuk menunjukkan subyek secara keseluruhan namun dapat diidentifikasi secara jelas, medium shot yang menunjukkan beberapa bagian subyek secara lebih rinci reaksi dan emosi subyek, medium close up yang menunjukkan ekspresi wajah subyek agar lebih jelas, serta two shot yang menunjukkan hubungan antara satu subyek dengan subyek lainnya yang saling berinteraksi dalam gerakan.

Tanda dan kode tersebut terdapat pada tataran denotasi dan konotasi(Wahyuningsih, 2019). Tataran denotasi dan konotasi meliputi latar, pemilihan karakter, dan teks. Tidak hanya itu, peneliti juga akan menganalisis nilai ideologis atau mitos yang ada di dalamnya. Hal tersebut sesuai dengan teori yang dikemukan oleh Fiske yang mengkategorikan kode-kode film ke dalam tiga level, yaitu realitas, representasi, dan ideologi (Fiske, 1987)

\section{HASIL DAN PEMBAHASAN}

\section{a. Realitas Aspek Tanda}

Realita di masyarakat bahwa perpustakaan merupakan gudang ilmu sudah terekam di benak mereka. Informasi tersebut pada umumnya diperoleh ketika mereka mengenal sekolah. Sejak dini mereka diberikan pengetahuan dasar dan diarahkan untuk ke perpustakaan memanfaatkan sumber bacaan yang ada sehingga dapat meningkatkan pengetahuan mereka. Sebagian besar siswa datang ke perpustakaan karena perintah gurunya bukan motivasi sendiri. Oleh sebab itu, para penulis buku melakukan kreasi agar buku mereka dapat dimanfaatkan oleh segmentasi pembacanya.

Misalnya saja untuk kategori target pembacanya siswa sekolah dasar, maka para penulis buku akan menyusun informasi dengan bahasa yang sederhana agar mudah dimengerti dan diserap oleh si anak, dibantu pula dengan ilustrasi gambar agar anak mudah menerjemahkan isi buku tersebut dengan imajinasi mereka. Pada masa ini, anak akan lebih mudah memahami jika dibantu dengan ilustrasi gambar dan warna.

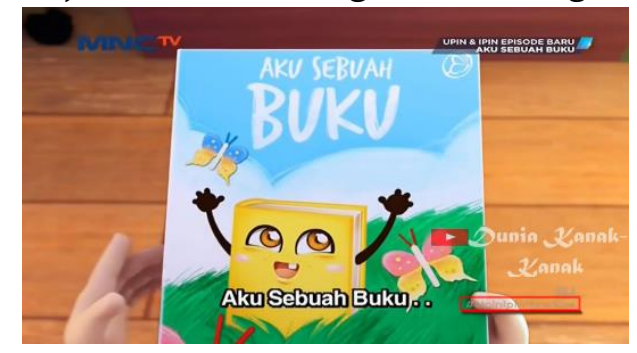

Gambar 1. Buku berjudul Aku Sebuah Buku

Sumber: Gerai Mutu Official (2018)

Dilihat dari secara visualisasi fisik buku dalam film, buku berjudul Aku Sebuah Buku sangat menarik, dari cover-nya terlihat penuh warna ditambah dengan ilustrasi 
animasi yang membuatnya semakin menarik untuk diketahui sehingga ini akan menjadi daya tarik anak-anak untuk membacanya.

Realitas berikutnya pada mobil perpustakaan keliling. Pada umumnya untuk menarik perhatian pemustaka terutama usia anak-anak, tidak hanya bukunya saja yang harus berwarna bahkan mobil sebagai prasarana perpustakaan keliling juga harus diwarnai untuk membangkitkan minat mereka menghampiri serta memanfaatkan koleksi buku yang ada di dalam mobil.

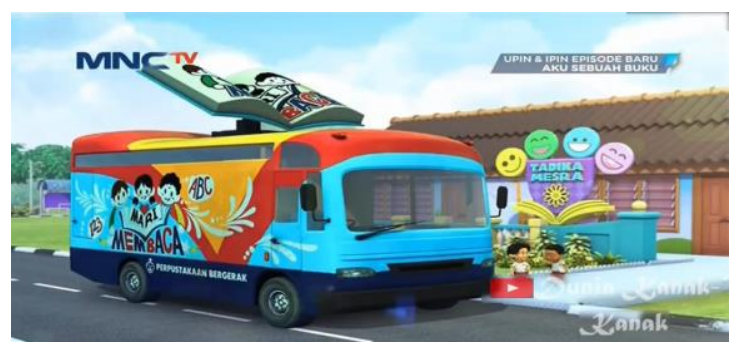

Gambar 2. Mobil Perpustakaan Keliling

Sumber: Gerai Mutu Official (2018)

Seperti terlihat di film mobil yang digunakan penuh warna dan gambar animasi yang menarik. Itu sebabnya Upin dan Ipin bersama teman-temannya di dalam film tersebut juga sangat antusias mendatangi mobil perpustakaan keliling yang berhenti tepat di depan sekolah taman kanak-kanak Tadika Mesra.

\section{b. Representasi Aspek Tanda}

Ada tujuh aspek penting yang diperlukan untuk melakukan penyelenggaraan sebuah perpustakaan, yakni organisasi, gedung/ruangan, perabot dan perlengkapan, koleksi, tenaga, layanan, dan anggaran (Opong, Rahayu, Rusmiyati, Sudarto, \& Bintari, 2014). Pada episode Aku Sebuah Buku merepresentasikan empat dari tujuh unsur yang ada. Pertama representasi gedung/ruangan di mana dalam film tersebut perpustakaan digambarkan sebagai salah satu tempat memperoleh ilmu dengan ruangan yang sangat besar sehingga cukup ideal menampung banyak pengunjung; lantai, meja, kursi, rak, dan buku-buku bersih tidak berdebu. Gambaran tersebut mengisyaratkan perpustakaan layak sebagai tempat belajar dan mencari ilmu yang representatif. 


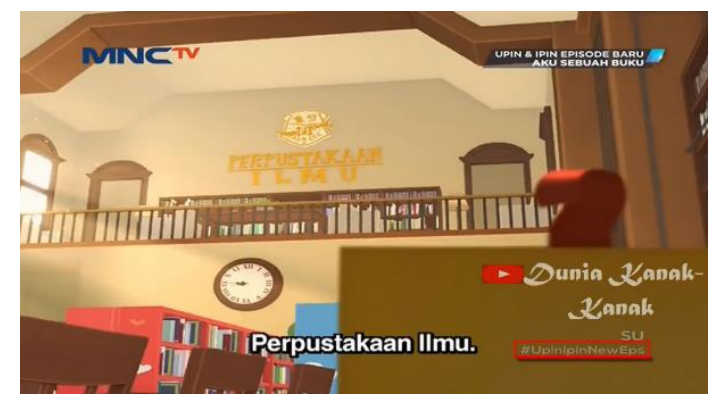

Gambar 3. Perpustakaan Ilmu

Sumber: Gerai Mutu Official (2018)

Nama Perpustakaan Ilmu digunakan seolah-olah merepresentasikan bahwa ruangan yang luas dengan koleksi di setiap rak merupakan kumpulan ilmu yang dapat bermanfaat.

Kedua, representasi perabot dan peralatan yang lengkap, bersih, dan berfungsi dengan baik juga digambarkan dalam film ini. Idealnya sebuah perpustakaan dapat berjalan lancar jika memiliki sarana dan prasarana yang lengkap dan memadai.

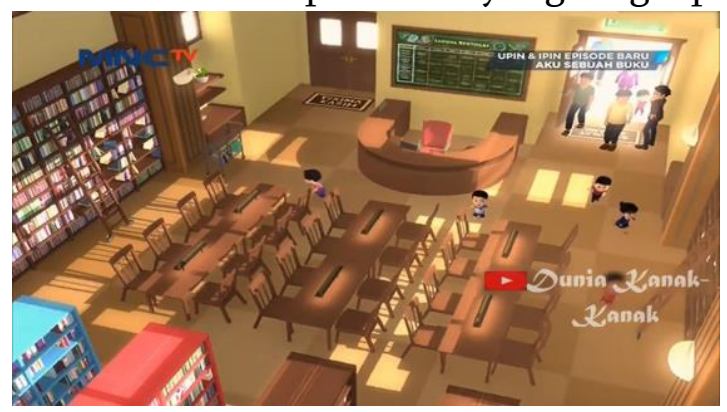

Gambar 4. Ruangan Perpustakaan Ilmu

Sumber: Gerai Mutu Official (2018)

Dilihat dari gambar tersebut, Perpustakaan Ilmu memiliki meja dan kursi yang sangat memadai dan diatur dengan rapi dan proporsional. Tata letak antara rak buku, ruang baca, dan meja layanan sirkulasi, dan penerangan diatur sedemikian rupa sehingga membuat pemustaka aman dan nyaman berada di perpustakaan.

Ketiga, representasi penataan koleksi yang tertata rapi menunjukkan adanya tanggung jawab pengelola perpustakaan untuk memberikan kenyamanan dan kemudahan bagi pengunjung dalam menemukan informasi yang dibutuhkan. Kebaragaman dan kebaruan koleksi juga menjadi daya tarik pemustaka untuk berkunjung ke perpustakaan. Oleh sebab itu pengelola perpustakaan juga harus memperhatikan pengembangan koleksi perpustakaan. 


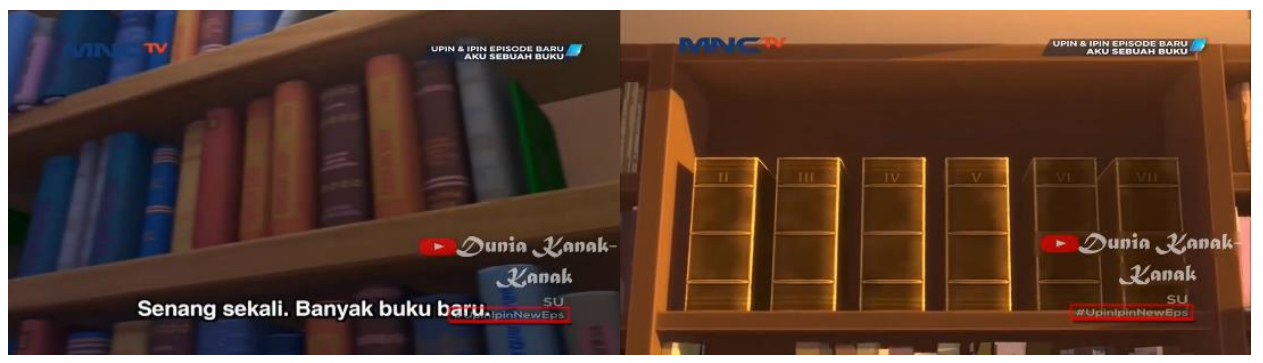

Gambar 5. Koleksi Buku

Sumber: Gerai Mutu Official (2018)

Namun sangat disayangkan, kemajuan teknologi mengubah perilaku masyarakat yang mengakibatkan berkurangnya minat masyarakat berkunjung ke perpustakaan walaupun koleksi yang ada sudah mutakhir dan beraneka ragam. Seperti yang digambarkan oleh pemeran Atok, Upin, dan Ipin dalam film ini.

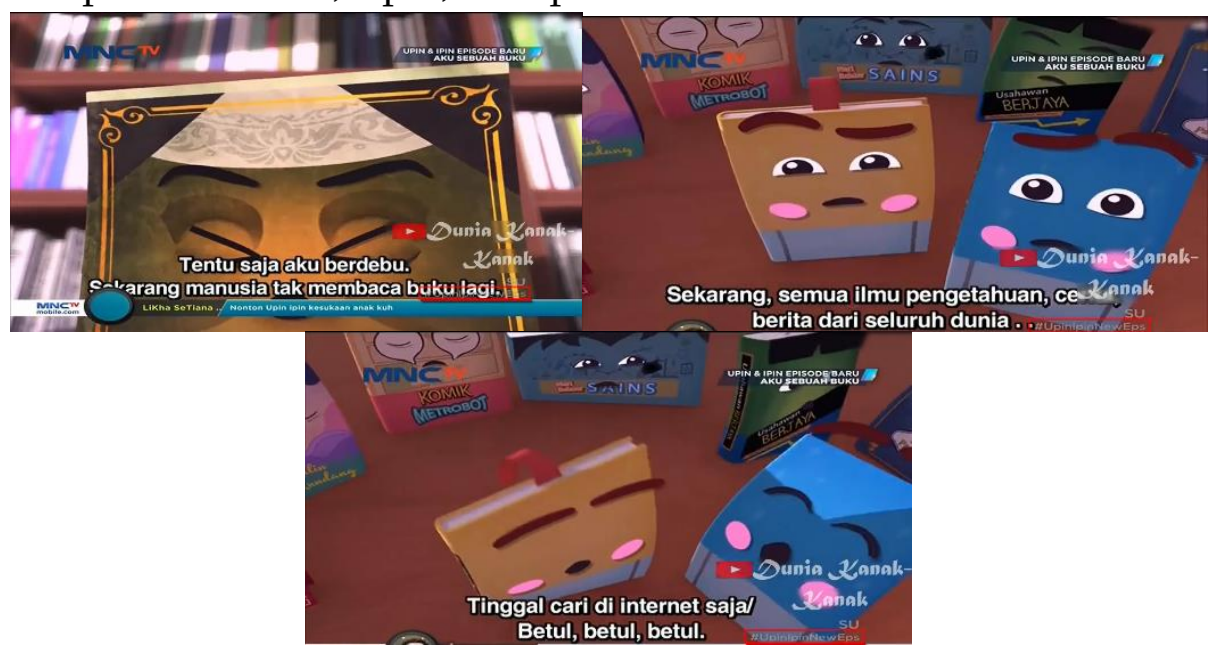

Gambar 6. Kondisi Ensiklopedia yang Berdebu Sumber: Gerai Mutu Official (2018)

Keempat, representasi petugas yang disebut dengan pustakawan. Dalam film ini, pustakawan direpresentasikan sebagai petugas yang ramah dan siap melayani semua kebutuhan pemustaka.

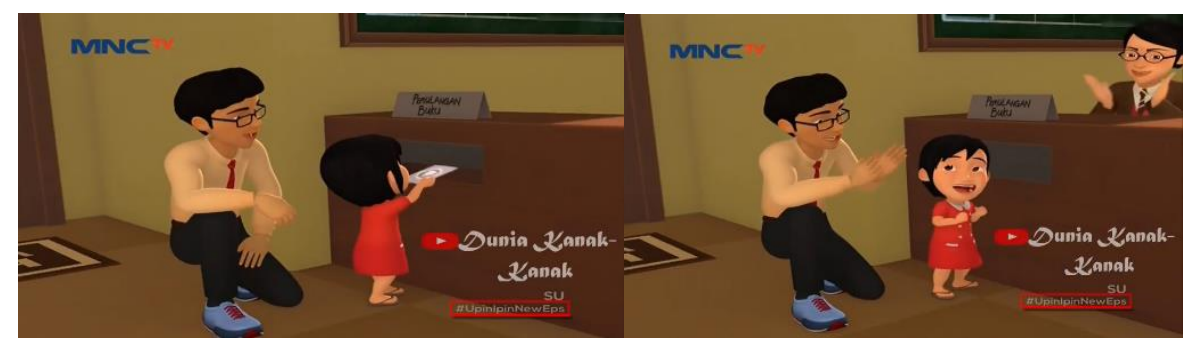

Gambar 7.Pustakawan Membantu Pemustaka

Sumber: Gerai Mutu Official (2018) 
Gambaran tersebut menegaskan bahwa pentingnya peran pustakawan dalam sebuah perpustakaan, tidak hanya dalam pengadaan dan pengolahan koleksi tapi juga memberikan kenyamanan layanan kepada pemustaka. Pada potongan film juga terlihat pustakawan memberikan edukasi kepada pemustaka bagaimana proses pengembalian buku.

\section{c. Ideologi Aspek Tanda}

Paradigma masyarakat selama ini perpustakaan adalah sebuah gedung dengan jajaran rak yang dipenuhi buku dan meja baca. Oleh sebab itu perlu adanya pemahaman dan merubah pola pikir bahwasanya perpustakaan merupakan jendela dunia dan penuh ilmu pengetahuan. Semua aspek masyarakat harus berperan aktif dalam mengembangakan perpustakaan dan menanamkan minat baca pada anak sejak dini sehingga membuat mereka ketergantungan pada perpustakaan.

Seperti yang terlihat di dalam film ini, bagi negera Malaysia, meskipun segala informasi dapat diperoleh dengan mudah dan cepat melalui internet namun mereka tetap memiliki semangat yang tinggi dan menghargai buku di perpustakaan sebagai sumber ilmu utama. Hal tersebut tergambarkan melalui ramainya pengunjung perpustakaan yang memenuhi Perpustakaan Ilmu.

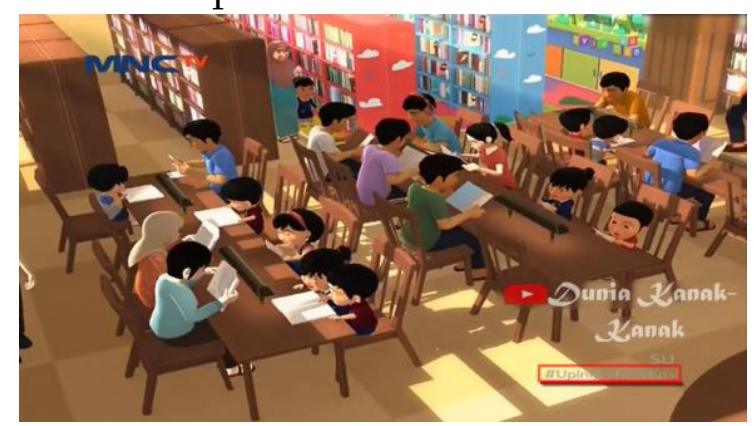

Gambar 8. Pengunjung Perpustakaan

Sumber: Gerai Mutu Official (2018)

Mereka terlihat fokus dan asik pada bacaan masing-masing. Semua dalam kondisi yang nyaman dan tenang saat membaca, tidak kalah menarik perpustakaan juga terbuka untuk semua kalangan, baik usia anak-anak, remaja, maupun dewasa.

\section{d. Realitas Aspek Kode}

Pada film ini mengambil latar di perpustakaan keliling dan juga gedung perpustakaan yang tertata rapi, bersih, dan ideal berdasarkan standar perpustakaan. Di Malaysia tugas menjaga dan merawat fasilitas ublic adalah tanggung jawab bersama, dan sangat menghargai fasilitas yang disediakan oleh pemerintah. Hal tersebut ditunjukkan dari antusiasme Upin dan Ipin beserta teman-temannya yang menghampiri mobil 
perpustakaan keliling "cepat-cepat" dan terkesima dengan koleksi-koleksi yang tertata rapi di mobil tersebut.
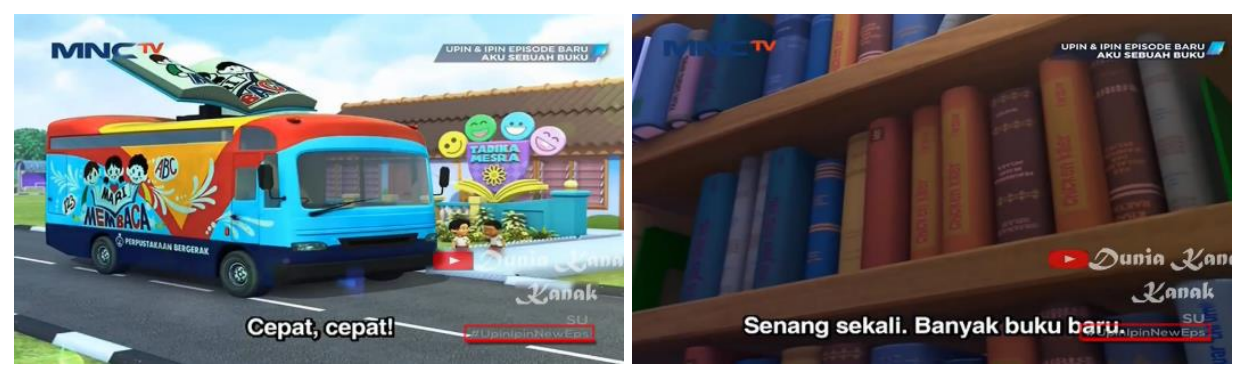

Gambar 9. Antusias menuju Mobil Perpustakaan Keliling

Sumber: Gerai Mutu Official (2018)

Gambaran ini memperlihatkan kepedulian pemerintah dalam mencerdaskan anakanak sejak usia dini yakni mengedukasi melalui pengenalan dan pemanfaatan buku perpustakaan melalui film animasi favorit. Strategi ini bisa menjadi referensi menumbuhkan minat baca sejak dini sehingga aktivitas membaca bisa membudaya. Promosi perpustakaan bukan hanya bertujuan untuk menginformasikan fasilitas yang ada tapi juga bagaimana menjaganya.

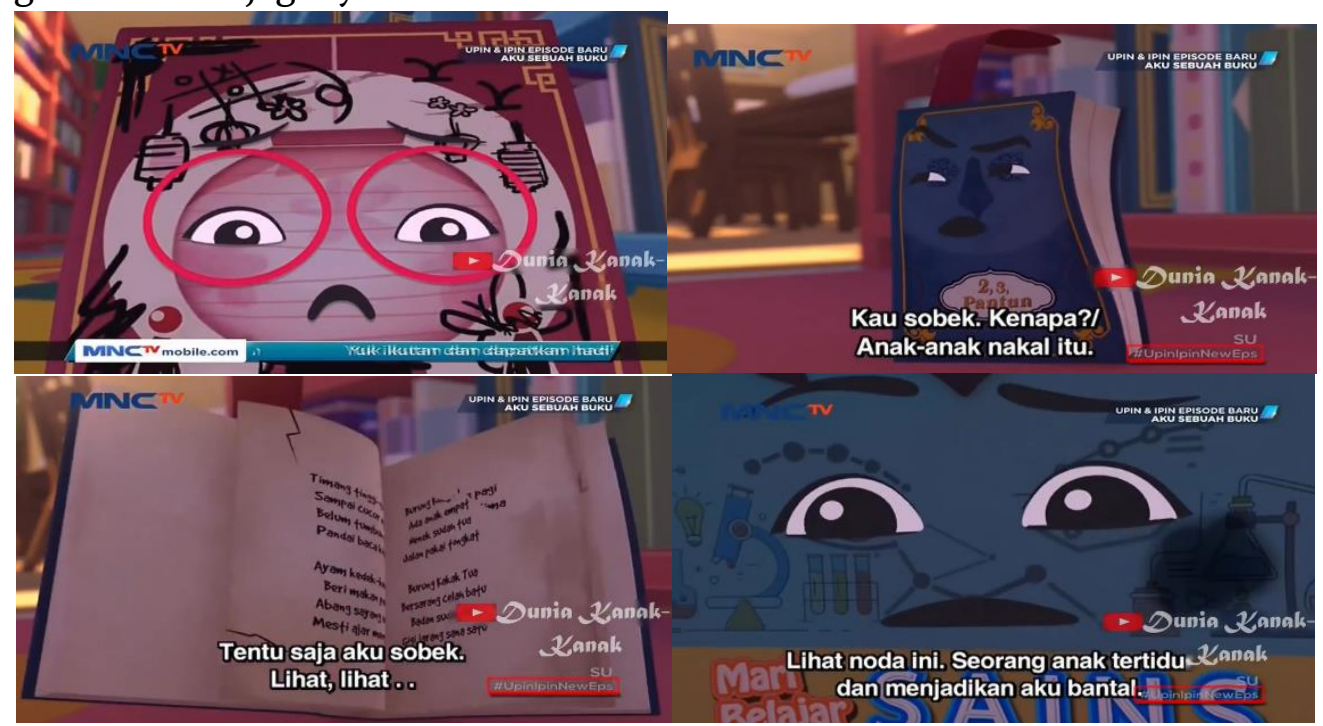

Gambar 10. Vandalisme oleh pemustaka anak-anak Sumber: Gerai Mutu Official (2018)

Pemustaka harus mengetahui buku milik umum itu harus dijaga dan dirawat dengan baik agar buku tersebut dapat digunakan dengan baik. Namun tidak dimungkiri bahwa ada sebagian besar anak-anak yang tidak memahami arti penting merawat buku. Hal tersebut dapat dilihat dalam adegan buku Mei-Mei yang bagian covernya dicoret-coret dengan spidol, serta buku Jarjit yang disobek-sobek di beberapa halaman.

Perilaku seperti itu terlihat remeh namun berdampak besar, itulah fandalisme. Untuk mengurangi pengrusakan terhadap buku, maka konten dalam film ini sangat menarik 
karena menginformasikan bahwa buku milik perpustakaan tidak boleh dicoret-coret ataupun juga disobek-sobek baik sengaja maupun tidak disengaja. Tindakan pengrusakan koleksi akan mengakibatkan informasinya tidak bisa diterima dengan utuh.

Buku-buku yang rusak dan dinilai tidak layak pakai akan segera ditindaklanjuti dengan cara menyisihkannya (weeding). Jika sudah demikian maka koleksi buku akan berkurang akibat dari tingginya tingkat vandalism pemustaka.

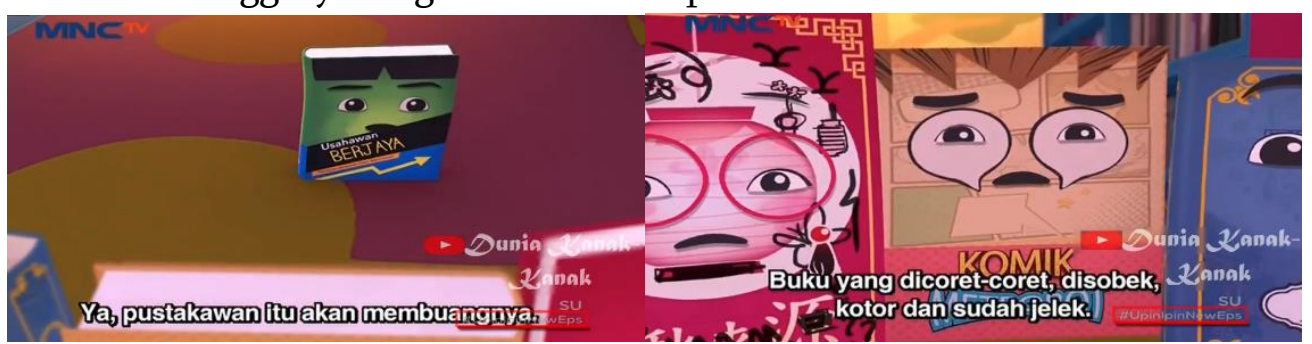

Gambar 11. Kebijakan Penyiangan Buku

Sumber: Gerai Mutu Official (2018)

Pada realitasnya, tidak semua buku yang ada di perpustakaan dalam kondisi yang baik, itu disebabkan karena fandalisme. Padahal pengembangan koleksi belum tentu dilakukan rutin setiap tahunnya di setiap jenis perpustakaan, oleh sebab itu buku sebagai aset penting suatu lembaga perlu dijaga dan dilestarikan.

\section{e. Representasi Aspek Kode}

Ada beberapa objek yang direpresentasikan di dalam film ini, seperti pustakawan, pemustaka, dan tokoh masyarakat. Beberapa adegan pustakawan muncul dan menyiratkan sikap pustakawan sehingga membentuk representasi pustakawan melalui film ini. Sejak awal adegan, pustakawan yang menjaga mobil perpustakaan keliling memperingati pemustaka agar menjaga kenyamanan dan ketenangan. Jika terjadi keributan akan mengganggu konsentrasi pemustaka lainnya.

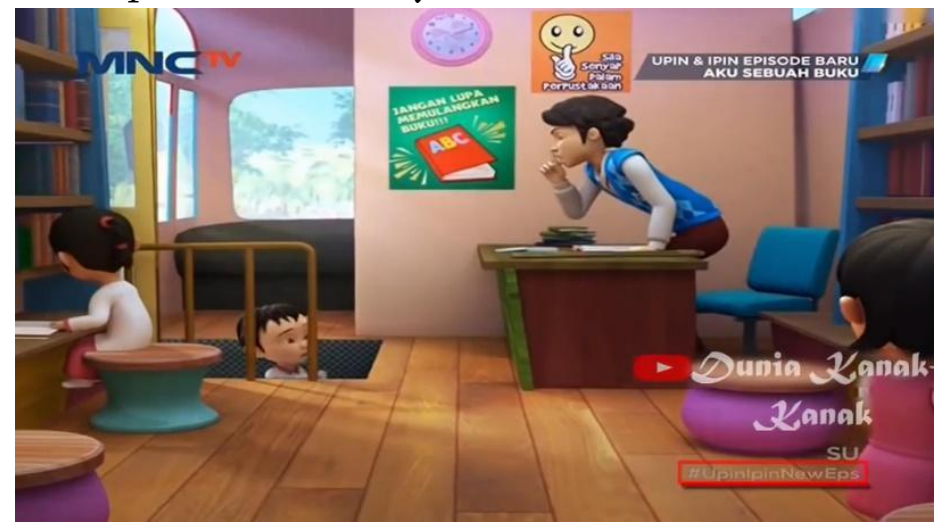

Gambar 12. Pustakawan memperingati pemustaka

Sumber: Gerai Mutu Official (2018) 
Adegan berikutnya pustakawan di Perpustakaan Ilmu memberikan ekspresi menggerutu dikarenakan pemustaka yang tidak disiplin menaruh buku pada raknya.

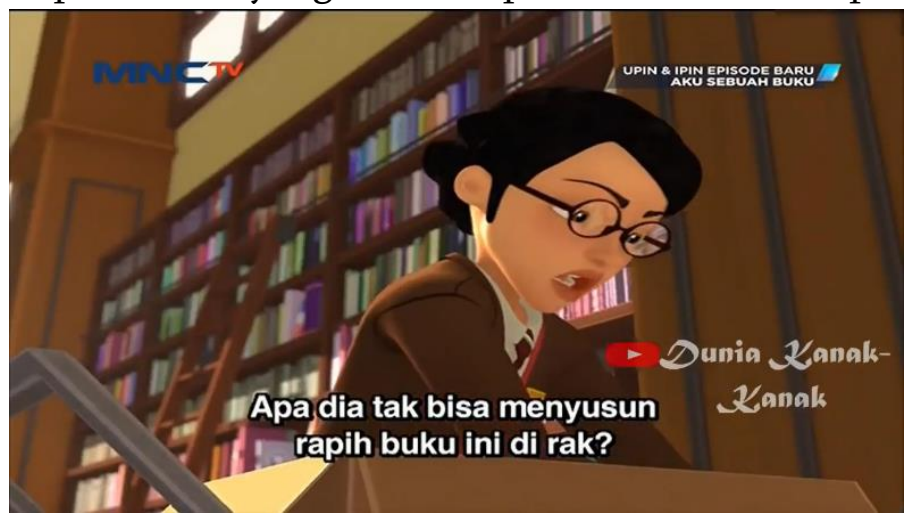

Gambar 13. Pustakawan merapikan buku berserakan

Sumber: Gerai Mutu Official (2018)

Pustakawan juga manusia yang memiliki perasaan, bukan berarti pemustaka dapat seenaknya meletakkan buku yang telah dibacanya. Ketika mendapati hal tersebut, pustakawan memberikan ekspresi menggerutu seolah-olah sedang marah kecil terhadap sikap pemustaka tersebut. Namun di sisi lain, pustakawan tetap profesional, sigap merapikan buku yang berserakan tersebut.

Adegan selanjutnya pustakawan mempertegas jikalau pustakawan sigap melayani pemustaka. Hal tersebut tergambar dari cara pustakawan yang ramah ketika jam layanan perpustakaan berakhir dan mengingatkan pemustaka untuk senantiasa datang kembali ke perpustakaan.

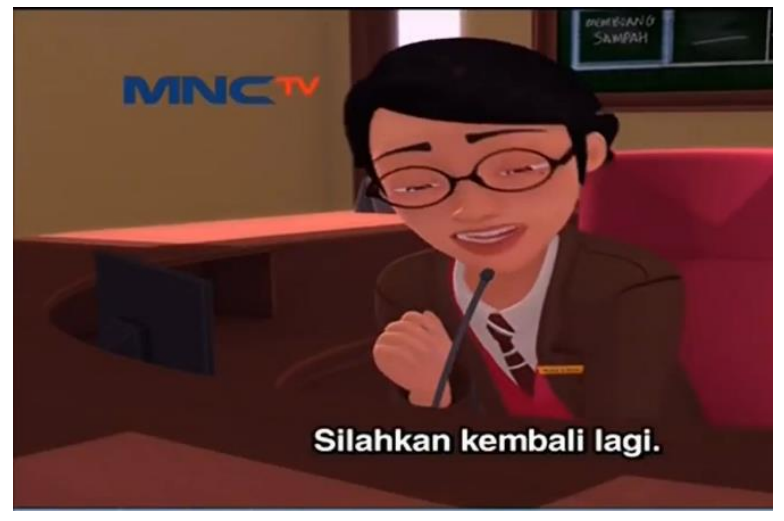

Gambar 14. Keramahan Pustakawan

Sumber: Gerai Mutu Official (2018)

Bahkan pustakawan selalu mengingatkan jika membaca merupakan jembatan ilmu. Terkesan sederhana namun jika dilakukan berulang kali dapat memberi dampak akan selalu melekat dihati pemustaka. Hal ini juga bisa menjadi kegiatan promosi perpustakaan secara lisan. 
Adegan berikutnya merepresentasikan pemustaka di perpustakaan. Adegan pertama diawali dengan ekspresi Upin dan Ipin yang tertarik membaca buku bergambar berjudul Aku Sebuah Buku.

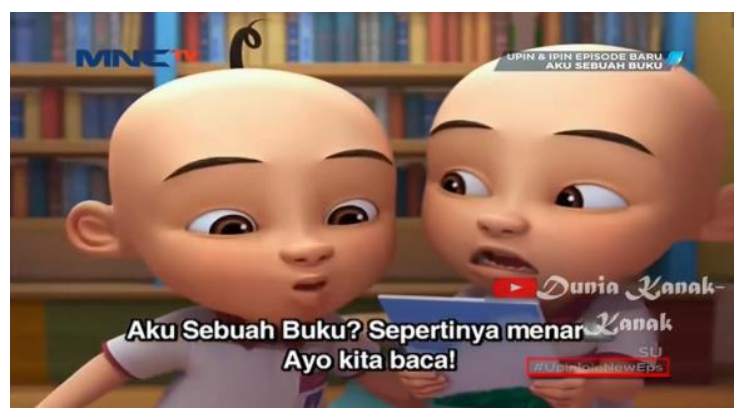

Gambar 15. Upin dan Ipin Tertarik Membaca Sumber: Gerai Mutu Official (2018)

Upin melihat buku tersebut penuh warna dan judulnya yang sederhana terlihat menarik untuk dibaca. Ini menandakan pemustaka anak akan terpikat pada buku yang secara fisik penuh warna dan judul yang unik. Menariknya lagi, pemustaka yang datang berkunjung ke perpustakaan tidak hanya kalangan anak-anak tetapi keluarga yang mengedukasi anak mereka untuk membaca buku.

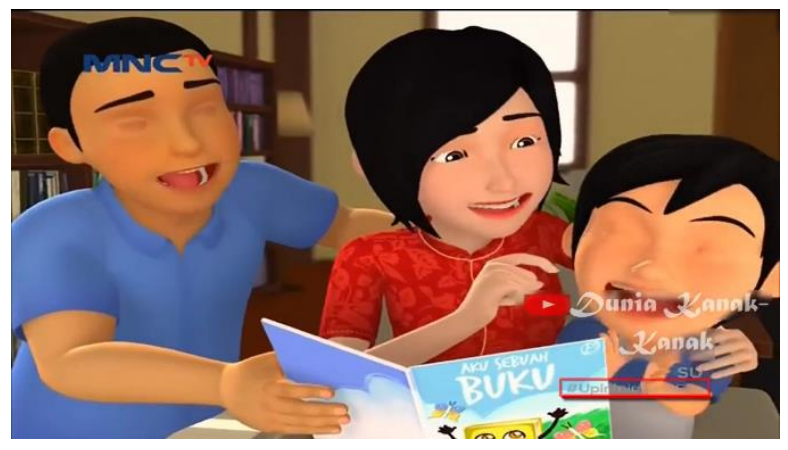

Gambar 16. Orang tua mendampingi anak membaca di perpustakaan Sumber: Gerai Mutu Official (2018)

Peran orang tua sebagai role model bagi anak sangat berpengaruh. Adegan pada film ini menunjukkan kelekatan yang ditunjukkan dari keluarga kecil yang mendampingi anaknya membaca di perpustakaan, berbagi cerita bersama, dan bercerita secara interaktif seolah anak diajak bercerita akan menambah nilai pengalaman bagi si anak.

Adegan lainnya Orang tua mengedukasi anaknya agar membaca dengan tenang. Selain agar tidak mengganggu ketertiban umum, membaca dengan tenang akan membantu pembaca lebih menghayati isi bacaan. Peran orang tua sangat berperan dalam menjaga sikap anak di fasilitas umum seperti halnya perpustakaan. 


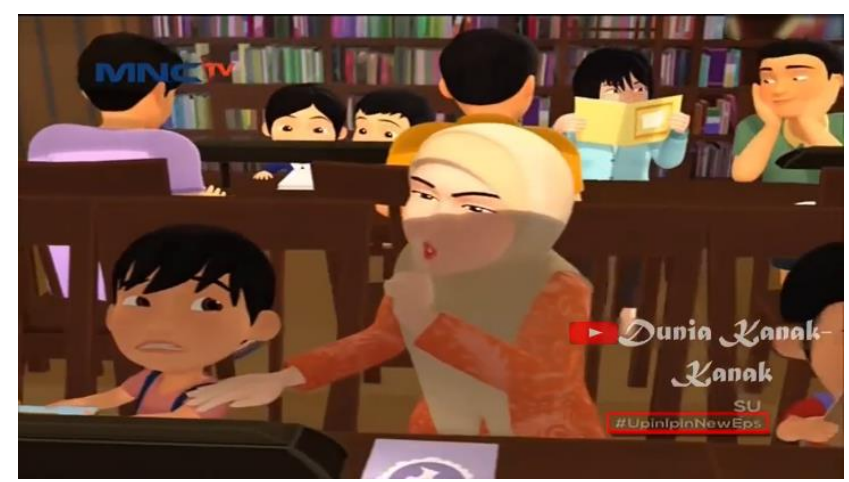

Gambar 17. Orang tua memperingati anaknya

Sumber: Gerai Mutu Official (2018)

Representasi terakhir mengenai kehadiran tokoh masyarakat, tokoh ini seolah ingin menunjukkan jika seorang cendekiawan hobi membaca dan mengunjungi perpustakaan. Untuk bisa menjadi orang yang berprestasi, dikenal banyak orang maka seseorang harus mau membaca agar pengetahuannya luas. Namun, tokoh tersebut terlihat sedih, saat membaca mendapati kondisi buku yang sobek dan hilang di beberapa halaman. Ia menyayangkan sikap pemustaka yang tidak bisa menjaga buku.

\section{f. Ideologi Aspek Kode}

Pada umumnya di perpustakaan harus tertib dan tenang. Namun kini perpustakaan modern dengan konsep learning commons mulai fleksibel. Perpustakaan mengalami kemajuan mengikuti perilaku dari masyarakat yang dilayaninya. Oleh sebab itu, baik jenis layanan maupun koleksi perpustakaan juga berkembang sesuai kebutuhan pemustaka. Pada film ini masih menunjukkan perpustakaan dengan konsep tradisional di mana para pemustaka harus duduk dengan tenang saat membaca di ruang perpustakaan.

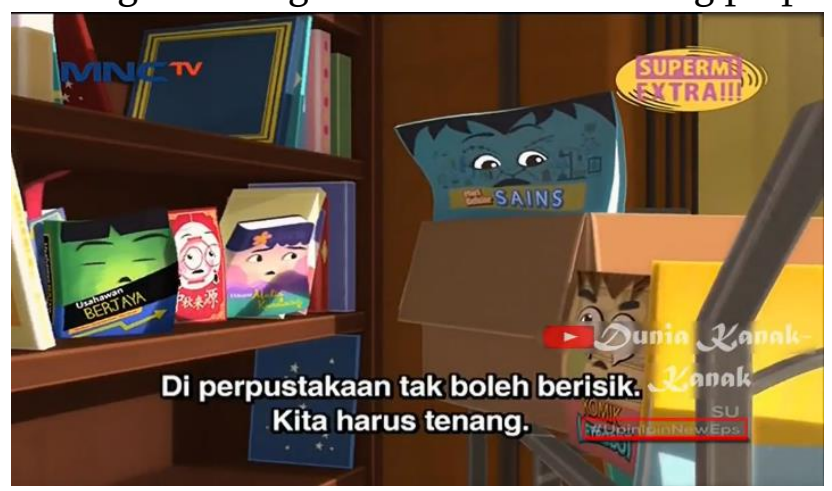

Gambar 18. Adegan tidak boleh berisik

Sumber: Gerai Mutu Official (2018)

Adegan tersebut sebagai edukasi bagi anak-anak yang menonton, jika berada di perpustakaan harus dalam keadaan tenang agar tidak mengganggu pemustaka lainnya. Membaca membutuhkan konsentrasi untuk menelaah isi bacaan. Terlebih lagi bacaan 
yang sepenuhnya teks maka butuh konsentrasi ekstra dalam menangkap makna yang terkandung di dalamnya.

Di akhir film, Upin dan Ipin memberi pesan secara eksplisit, ia menyerukan kepada anak-anak seusianya agar dapat manjaga dan menghargai buku karena buku adalah jembatan ilmu.

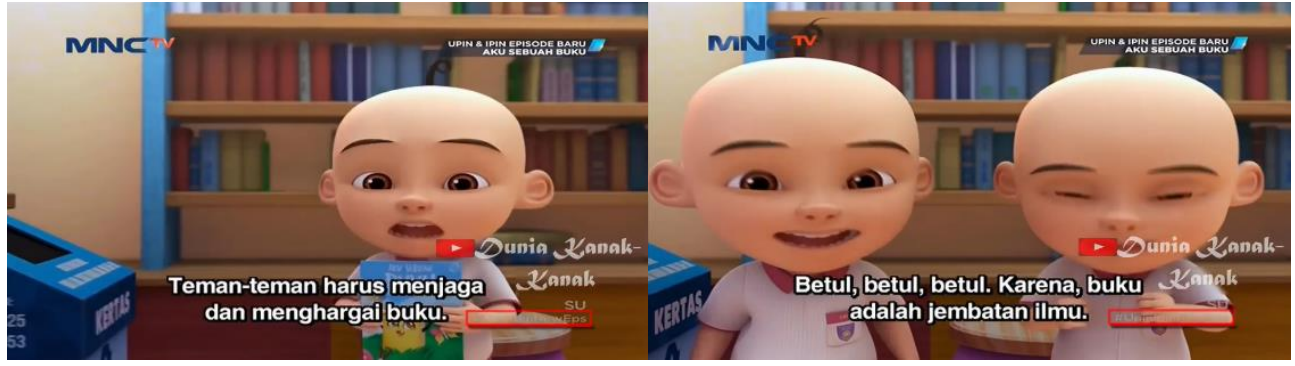

Gambar 19. Pesan dari Upin dan Ipin

Sumber: Gerai Mutu Official (2018)

Dalam adegannya, mereka menunjukkan jika buku yang telah rusak secara fisik dan isinya maka buku tersebut dapat dikategorikan kedalam buku yang tidak layak pakai sehingga harus didaur ulang atau disingkirkan dari jajaran koleksi. Tentu saja ini merugikan bagi perpustakaan dan pemustaka karena sumber bacaan akan berkurang.

\section{g. Strategi Promosi Perpustakaan}

Promosi perpustakaan dilakukan untuk menyampaikan pesan tentang produk (koleksi) dan jasa (layanan) yang dimiliki kepada pemustaka sehingga dapat membantu perpustakaan dalam meningkatkan jumlah kunjungan, pemanfaatan, hubungan baik, dan eksistensi. Dibalik itu, secara garis besar tujuan promosi untuk mengedukasi pemustaka bagaimana cara menggunakan perpustakaan dan sumber daya yang ada serta memelihara informasi yang dilampirkan dalam berbagai sumber yang tersedia di perpustakaan (Patil \& Pradhan, 2014). Fungsi utamanya seperti yang diungkapkan oleh Shimp (2010)yakni informing, persuading, reminding, dan adding value .

Bagi perpustakaan yang baru berdiri atau memiliki inovasi baru dapat menggunakan promosi untuk menginformasikan kepada para target pemustaka potensialnya agar mengenal dan mengetahui secara keseluruhan mengenai perpustakaan tersebut. pada umumnya promosi yang biasa digunakan kebanyakan perpustakaan menggunakan media brosur, buku pedoman, ataupun booklet. Lain halnya lagi bagi perpustakaan yang sudah cukup lama berdiri dan memiliki layanan serta koleksi yang cukup bervariatif, promosi digunakan untuk membujuk para target pemustaka agar mau berkunjung dan memanfaatkan layanan serta koleksi-koleksi tersebut. Sedangkan bagi perpustakaan yang sudah berdiri lama, layanan dan koleksi yang sangat variatif dapat menggunakan promosi untuk mengingatkan dan menambah 
nilai bagi para pemustaka aktifnya. Dengan kata lain, promosi dapat dilakukan dengan dua segmentasi yakni ditujukan bagi pemustaka potensial atau pemustaka aktif. Tim pemasar perlu memperjelas segmentasi targetnya.

Banyak cara yang dilakukan sebuah perpustakaan untuk melakukan promosi, mulai dari yang tidak berbayar hingga yang berbayar dengan anggaran yang cukup besar. Namun banyak juga perpustakaan yang tidak memiliki kesempatan untuk melakukan promosi sehingga berimbas pada menurunnya semangat kerja pustakawan karena koleksi yang dimiliki perpustakaan kurang peminatnya, kunjungan ke perpustakaan juga tidak meningkat (Holley, 2020). Oleh sebab itu, para pengelola perpustakaan perlu melihat peluang dan mencari kesempatan untuk melakukan promosi. Sudah menjadi kewajiban bagi setiap pengelola perpustakaan untuk menyuarakan dan gencar melakukan promosi agar perpustakaannya dimanfaatkan secara optimal oleh para pemustaka.

Ada beberapa strategi promosi yang dapat dilakukan sebuah perpustakaan untuk mencapai target promosinya. Untuk melakukan promosi perpustakaan bukan hanya dilihat pada kecukupan anggaran tetapi bagaimana mengatur strategi yang tepat meskipun perpustakaan hanya memiliki dana yang minim. Misalnya saja sebuah perpustakaan yang sudah memiliki website sebagai media informasinya dapat memanfaatkan laman depan untuk membuat iklan mengenai layanan baru, koleksi baru, ataupun cara pemanfaatan e-resources.

Webiste perpustakaan dianggap sebagai alat penemuan informasi yang paling komprehensif. Bahkan penempatan iklan di halaman situs web akan berdampak efektif terhadap pemustaka (Rogers \& Nielsen, 2017). Ada beberapa strategi promosi perpustakaan yang dapat dilakukan bagi perpustakaan yang memiliki anggaran terbatas: networking, institutional intranet, institutional newsletters and student magazine, free online training materials and tutorials, partnering with information communication technology (ICT) departments, partnership with students, word of mouth, youtube, library website, social media, integrating on the online public access catalogue, giveaways, and branding (Ndungu, 2016).

Tidak ada salahnya perpustakaan memanfaatkan jaringan yang ada untuk mempromosikan layanan dan koleksi yang dimiliki seperti menautkan link website perpustakaan pada institusinya sehingga berpotensi besar untuk meningkatkan visibilitas saat pemustaka mengakses laman website institusinya. Perpustakaan juga dapat memanfaatkan jaringan intranet institusi untuk mempromosikan perpustakaannya kepada pemustaka secara terbatas. Bahkan perpustakaan juga dapat menyisipkan informasi mengenai perpustakaannya pada buletin ataupun majalah internal institusi. 
Upaya-upaya sederhana tersebut dapat berdampak besar jika dilakukan secara kontinyu dan inovatif. Semakin sering informasi tersebut disampaikan maka semakin besar pula peluang informasi tersebut diingat oleh pemustaka. Berikutnya tinggal mengukur keberhasilan promosi dengan tiga tahapan, meliputi months prior to promotion, during promotion, and after promotion (Rogers \& Nielsen, 2017). Pengukuran dapat digambarkan dengan grafik ataupun diagram untuk memperjelas statistik pemustaka selama bulan-bulan sebelum melakukan promosi, selama promosi, dan setelah promosi untuk memudahkan analisis evaluasi kegiatan promosi.

Tantangan berat di era informasi, keberadaan perpustakaan mulai terancam, di mana sekarang orang dengan mudahnya mendapatkan informasi di manapun dan kapanpun mereka butuhkan. Namun di sisi lain, teknologi digital menyediakan saluran distribusi baru bagi pemasar, yang justru menciptakan peluang baru untuk mengukur perilaku pemustaka untuk memahami dampak efek lintas media seperti menggunakan film (Gong, Smith, \& Telang, 2015). Pada dasarnya, promosi yang baik tidak hanya memerlukan anggaran tetapi perlu keseriusan, mulai dari analisis segmentasi pasar, perencanaan pelaksanaan promosi, konsep program yang matang, pemilihan media efektif, merancang komunikasi pemasaran, serta evaluasi untuk mencapai target promosi. Tidak kalah penting dalam pemilihan media efektif yang merupakan kunci keberhasilan (Umiker-Sebeok, 2012).

\section{h. Film Sebagai Media Edukasi Pemustaka}

Pada pembahasan sebelumnya telah disampaikan bahwa tidak banyak perpustakaan yang memiliki kesempatan untuk melakukan promosi, salah satu penyebabnya karena minimnya anggaran perpustakaan. Jika merujuk pada penelitian yang dilakukan (Ndungu, 2016), ada beberapa strategi promosi yang dapat dilakukan jika memang suatu perpustakaan terkendala oleh anggaran. Namun perlu ditekankan lagi, bukan anggarannya yang menjadi alasan sebuah perpustakaan tidak melakukan promosi tetapi cara pandang pengelola perpustakaan yang mengupayakan untuk memenuhi tanggung jawabnya dalam bekerja, salah satunya melakukan promosi perpustakaan agar kunjungan dan keterpakaian koleksi meningkat.

Salah satu media promosi yang efektif mempengaruhi pasar sasaran yaitu film. Film mampu merepresentasikan dunia nyata untuk membuat para penonton terbawa ke dalam suasana alur cerita yang ditampilkan. Film sering digunakan sebagai rujukan untuk menjelaskan sesuatu agar mudah dipahami melalui pesan yang disampaikan oleh para pemerannya. Tidak jarang orang memilih menghabiskan waktu luang untuk menonton film favoritnya, bahkan anak-anak bisa bertahan berlama-lama menonton acara kartun favoritnya seharian di kala akhir pekan sebagai hiburan setelah lelah dengan rutinitas belajar di sekolah. 
Jean Jacques Rousseau menjelaskan perkembangan fungsi dan kapasitas kejiwaan manusia berlangsung dalam lima tahap, salah satunya berkembangan masa kanak-kanak (2 - 12 tahun) di mana perkembangan pribadi anak dimulai dengan makin berkembangnya fungsi indera anak untuk mengadakan pengamatan (Soemanto, 1990)(Soemanto, 1990). Ia menambahkan pula bahwa perkembangan setiap aspek kejiwaan anak pada usia tersebut didominasi oleh pengamatannya.

Pada umumnya usia inilah yang paling banyak menghabiskan waktu untuk mencari hiburan atau kesenangan bagi dirinya. Pada usia dini sangat potensial untuk mengajarkan kebiasaan-kebiasaan baik seperti membudayakan minat baca karena anakanak lebih mudah meniru segala sesuatu yang dilihatnya. Dari hal-hal yang dilihatnya akan membentuk proses sosio emosional dan kognitif. Bahkan televisi turut andil mempengaruhi perilaku anak.

Televisi termasuk media baru yang hampir dimiliki oleh seluruh lapisan masyarakat. Media tersebut berperan dalam menyampaikan informasi berupa berita, pengetahuan, hiburan dan memberi dampak bagi para penontonnya berupa pengetahuan, perilaku, bahkan pemikiran. Oleh sebab itu, media film sangat menarik digunakan sebagai media promosi untuk mengedukasi anak-anak tentang dunia perpustakaan, kondisi yang ada di perpustakaan juga akan sangat mudah diilustrasikan melalui gambar bergerak.

Sebuah perpustakaan tidak harus menciptakan sebuah film khusus bertema perpustakaan untuk mengedukasi pemustakanya. Dengan mencari referensi beberapa film yang menampilkan scene perpustakaan atau bahkan dapat menemukan secara khusus film yang mengangkat tema perpustakaan sudah merupakan langkah konkrit mempersiapkan promosi perpustakaan. Tentunya isi dari film tersebut dapat ditelaah terlebih dahulu sehingga bisa mempertimbangkan dampak positif ataupun negatifnya setelah menonton tayangan film tersebut.

Sebagai contoh film animasi Upin dan Ipin episode Aku Sebuah Buku yang mengangkat tema perpustakaan. Tema yang sangat jarang diangkat ke dalam sebuah film apalagi film hiburan yang berbentuk animasi dengan segmentasi penonton yang sudah jelas, rentang usia 2 - 12 tahun. Film animasi Upin dan Ipin yang tayang di stasiun televisi MNCtv merupakan salah satu dari berbagai film ber-genre hiburan yang ada di tanah air. Tema-tema yang dihadirkan menarik dan setiap episodenya mensiratkan pesan-pesan yang sangat mendidik. Pada episode kali ini, film Upin dan Ipin menonjolkan citra perpustakaan dari berbagai aspek agar dapat menginformasikan dan mengajak penonton mengenal perpustakaan dan tertarik untuk berkunjung serta memanfaatkan fasilitas yang ada.

Film menjadi strategi jitu untuk menarik pemustaka potensial, visualisasinya mudah diterima dan dipahami, sehingga dinilai efektif untuk mempengaruhi penonton. 
Seperti yang sudah dibahas melalui analisis semiotik Roland Barthes, film ini banyak menunjukkan citra positif, tidak hanya pada aspek gedung/ruangan, tetapi juga keramahan pustakawan saat melayani, aspek koleksi, dan fasilitas yang lengkap. Melalui film ini perpustakaan dimaknai sebagai tempat untuk memperoleh ilmu pengetahuan, bahkan bisa menjadi tempat rekreasi.

Selain itu film ini juga memberikan pesan bagaimana tata tertib dalam perpustakaan, saling menghargai satu sama lain, dan bagaimana cara merawat dan menjaga semua fasilitas, sarana dan prasarana yang di perpustakaan sehingga bisa dimanfaatkan secara maksimal oleh pemustaka. Artinya, ini menjadi sarana edukasi bahwa buku-buku yang ada di perpustakaan harus dijaga dan dipergunakan dengan baik, tidak boleh dirusak apalagi melakukan tindakan vandalisme yang sangat merugikan. Tentu hal ini sangat penting, karena agar buku-buku tersebut bisa digunakan kembali dikemudian hari oleh para pemustaka yang lain. Pustakawan sebagai salah satu faktor utama kesuksesan perpustakaan juga harus mampu melayani pemustaka dengan baik dan profesional. Kenyamanan dan kepuasan yang diterima oleh pemustaka akan menimbulkan rasa ketergantungan terhadap perpustakaan, sehingga pemustaka akan datang kembali ke perpustakaan.

Hal tersebut diperkuat dengan respon para informan yang telah menonton film ini, di mana mereka menyatakan bahwa film ini memberi pesan untuk menghargai buku, merawatnya, agar tidak merugikan orang lain ketika akan membaca buku di sebuah perpustakaan. Melalui film ini, para informan seolah menyadari kesalahan mereka selama ini terutama dalam hal memperlakukan buku sekolah yang mereka miliki. Tidak jarang mereka mencoret buku mereka untuk menandakan hal menarik yang telah dibaca atau membuat catatan kecil di halaman buku untuk mempermudah mereka mengingat kata kunci yang ingin dihapal berkaitan dengan tugas sekolah. Ternyata tindakan tersebut salah.

Mereka juga mengungkapkan kalau 2 diantara para informan tersebut pernah mengunjungi perpustakaan sekolah dan merobek buku yang ada sembari membaca dan bercanda dengan rekan sekelasnya. Pada waktu kejadian tersebut, tidak terpikirkan sama sekali bahwa perobekan tersebut akan berdampak bagi orang lain yang akan membaca buku tersebut. Ia hanya berpikir bahwa merobek buku akan menyebabkan ia dimarahi oleh petugas tanpa tahu dampak jangka panjang dari tindakan yang ia lakukan.

Hal ini menandakan anak-anak yang menjadi informan dalam penelitian ini lebih mudah menangkap pesan yang tersirat baik secara eksplisit maupun implisit melalui media audio visual dengan gambar bergerak seperti halnya film Upin dan Ipin. Rekaman mereka terhadap alur cerita dapat disampaikan dengan baik kepada peneliti sesuai dengan adegan per adegan yang ada di film. Bahkan mereka menceritakan 
dengan penuh ekspresi seolah mereka yang menjadi para pemain dalam film tersebut. Mereka juga sudah merencanakan untuk berkunjung ke perpustakaan seperti yang Upin dan Ipin lakukan.

Perencanaan oleh para informan diartikan sebagai aksi nyata dari aktivitas menonton film animasi tersebut. Ketika suatu film mampu mempengaruhi seseorang untuk bertindak maka ini menunjukkan keberhasilan pembuatan film tersebut. Dengan demikian, penayangan film animasi kepada para informan merupakan salah satu strategi promosi perpustakaan yang efektif untuk mengedukasi pemustaka potensial tentang peran dan fungsi perpustakaan. Penelitian ini membuktikan bahwa untuk melakukan promosi perpustakaan tidak harus dengan anggaran yang besar, namun pengelola perpustakaan perlu aktif dan kreatif menemukan peluang untuk melakukan promosi bagi perpustakaan yang dikelolanya. Dampaknya, mereka yang selalu dibanjiri dengan informasi promosi yang secara kontinyu dilakukan dapat berprilaku sesuai dengan harapan yakni berkunjung ke perpustakaan sehingga meningkatkan keterpakaian koleksi perpustakaan. Tujuan akhirnya adalah untuk memperoleh loyalitas pemustaka dan kunjungan yang agresif dari para pemustaka aktif dan potensial.

\section{SIMPULAN}

Film animasi Upin dan Ipin episode Aku Sebuah Buku memberikan gambaran realitas, representasi, dan ideologi pesan-pesan yang terkandung menonjolkan citra perpustakaan agar bisa diintepretasikan sebagai tempat yang nyaman untuk memperoleh pengalaman dan ilmu pengetahuan sehingga para penonton dapat merespon secara positif melalui sikap dan tindakan yang nyata setelah menonton film animasi tersebut. Dengan begitu pandangan perpustakaan sebagai tempat yang kaku, yang hanya menyimpan buku-buku di rak bisa dipatahkan dengan adanya film animasi Upin dan Ipin episode Aku Sebuah Buku.

Kelebihan film dapat menjadi media promosi jangka panjang karena esensi pesan yang disampaikan tidak mudah usang. Sehingga dapat diputar berkali-kali kapanpun dan di manapun secara intensif agar dapat mempengaruhi orang yang menontonnya. Film juga memudahkan para penonton menangkap makna yang disampaikan melalui komunikasi yang dilakukan baik dalam dialog maupun simbol-simbol yang muncul dalam film sehingga mudah diingat dan diaplikasikan.

Penelitian ini membuktikan bahwa strategi promosi dengan cara menggunakan media film sangat efektif dilakukan untuk mengenalkan perpustakaan kepada masyarakat, melalui audio dan visual yang dikemas dalam video film membuat pesan yang ingin disampaikan lebih masuk ke telinga dan ingatan masyarakat dengan cepat. Dengan kemajuan teknologi saat ini sangat membantu para pustakawan dalam 
mempromosikan perpustakaan, pembuatan sebuah video film pun tidak harus mengandalkan tenaga profesional dan anggaran yang besar, banyak sekali aplikasi dan platform online yang bisa digunakan dalam pembuatan video animasi, hanya butuh keaktifan dan kreatifitas hingga semuanya bisa terwujud.

Alternatif lainnya dapat juga memanfaatkan referensi film-film yang sudah ada namun perlu melakukan telaah sebelum menayangkan film tersebut kepada target pemustaka yang diinginkan. Solusi lainnya, para pustakawan juga dapat membuat film pendek dengan durasi terbatas yang nonkomersil mengenai perpustakaannya untuk kepentingan pemasaran. Film tersebut dapat diputar pada tempat-tempat strategis, misalnya saja di videotron perpustakaan, website perpustakaan, sosial media perpustakaan, atau bisa juga bekerja sama dengan instansi induk atau bahkan perusahaan sebagai bentuk program Corporate Social Responsibility (CSR) mereka untuk pendidikan. Mereka bisa menjadi sponsor untuk pembuatan film pendek nonkomersil tersebut sehingga meringankan anggaran untuk menciptakan promosi yang efektif.

\section{Kontribusi Pada Keilmuan}

Penelitian ini merupakan kajian dalam bidang Pemasaran Informasi yang mengkaji media promosi yang strategis. Penelitian ini juga berkaitan dengan bidang Literasi dan Minat Baca. Hasil penelitian ini dapat menjadi dasar untuk penelitian selanjutnya yang mengkaji Pemasaran Perpustakaan. Penelitian ini juga dapat menjadi sumber inspirasi bagi penelitian di bidang yang berhubungan dengan Literasi.

\section{Pernyataan Minat Kajian}

Peneliti memiliki minat kajian dalam bidang Pengembangan Minat Baca dan Pemasaran Informasi.

\section{Kontribusi Peneliti dan pihak lain}

Peneliti menyiapkan instrumen pedoman wawancara dan analisis data

\section{Kontribusi Pihak Lain}

Peneliti mengucapkan terima kasih kepada para informan dan asisten peneliti yang telah membantu dalam pengumpulan data.

\section{DAFTAR PUSTAKA}

Adhyria, F. A. (2015). Strategi Promosi Perpustakaan Khusus (Studi Pada Bank Indonesia Surabaya). Jurnal Administrasi Publik, 3(12), 2101-2106. Retrieved from administrasipublik.studentjournal.ub.ac.id/index.php/jap/article/view/1101

Afriani, N., \& Yunaldi. (2012). Peranan Promosi Perpustakaan Terhadap Kunjungan Pemustaka di Perpustakaan Umum Kota Solok. Jurnal Ilmiu Informasi Perpustakaan Dan Kearsipan, 1(1), 9-16. https://doi.org/https://doi.org/10.24036/331-0934 
Amiruddin, A. (2018). Upin dan Ipin Musim 12: Aku Sebuah Buku. Malaysia.

Fiske, J. (1987). Television Culture. London: Routledge.

Gong, J., Smith, M. D., \& Telang, R. (2015). Substitution or Promotion ? The Impact of Price Discounts on Cross-Channel Sales of Digital Movies. Journal of Retailing, 91(2), 343-357. https://doi.org/10.1016/j.jretai.2015.02.002

Hackley, C. E. (2005). Advertising and Promotion: Communicating Brands. London: Sage Publications.

Holley, R. P. (2020). Promotion: An Intractable Management Problem for Academic and Public Libraries. Journal of Library Administration, 60(5), 550-558. https://doi.org/https://doi.org/10.1080/01930826.2020.1760565

Kotler, P., \& Keller, K. L. (2009). Manajemen Pemasaran (13th ed.). Jakarta: Erlangga.

Mudjiyanto, B., \& Nur, E. (2013). Semiotics In Research Method of Communication [Semiotika Dalam Metode Penelitian Komunikasi]. Pekommas, 16(1), 73-82. https://doi.org/10.30818/jpkm.2013.1160108

Ndungu, M. W. (2016). Promotion of Electronic Resources in Academic Libraries on a Minimal Budget. International Information and Library Review, 48(2), 94-101. https://doi.org/https://doi.org/10.1080/10572317.2016.1176449

Noor, F., \& Wahyuningratna, R. N. (2017). Representasi Sensualitas Perempuan Dalam Iklan New Era Boots di Televisi. Ikhraith-Humaniora, 1(2), 1-10. Retrieved from https://journals.upi-yai.ac.id/index.php/ikraith-humaniora/article/view/140

Opong, S., Rahayu, L., Rusmiyati, Y., Sudarto, \& Bintari, R. (2014). Pengelolaan Perpustakaan Sekolah. Tangerang Selatan: Universitas Terbuka.

Patil, S. K., \& Pradhan, P. (2014). Library promotion practices and marketing of Library services : A role of Library professionals. Procedia - Social and Behavioral Sciences, 133, 249-254. https://doi.org/10.1016/j.sbspro.2014.04.191

Rogers, J., \& Nielsen, J. (2017). Assessing a Promotional Strategy for Marketing Electronic Resources in the Library Environment. The Serials Librarian, 73(1), 18-26. Retrieved from https://doi.org/10.1080/0361526X.2017.1317687

Shimp, T. A. (2010). Integrated Marketing Communications in Advertising and Promotion (8th ed.). England: South-Western Cengage Learning.

Soemanto, W. (1990). Psikologi Pendidikan: Landasan Kerja Pemimpin Pendidikan. Jakarta: Rineka Cipta.

Umiker-Sebeok, J. (2012). Marketing and Semiotics: New Directions in the Study of Signs 
for Sale. Amsterdam: Walter de Gruyter.

Wahjuwibowo, I. S. (2013). Semiotika Komunikasi: aplikasi praktis bagi penelitian dan skripsi komunikasi (3rd ed.). Jakarta: Mitra Wacana Media.

Wahyuningsih, S. (2019). Film \& Dakwah: Memahami representasi pesan-pesan dakwah dalam film melalui analisis semiotik. Surabaya: Media Sahabat Cendekia.

Yao, X. (2012). Evaluation and promotion : The cooperative purchase experience of academic libraries in China. Library Collections, Acquisitions and Technical Services, 36(3-4), 97-106. https://doi.org/10.1016/j.lcats.2012.05.003 
Strategi promosi perpustakaan: Film animasi sebagai media edukasi bagi pemustaka (Atiqa Nur Latifa Hanum) 